\title{
CHRONIC CATHETERIZATION OF BLOOD VESSELS IN THE DOG*
}

\author{
David Evans, M.B., CH.B., F.R.C.P. (c), \\ AND H. W. BOYEs, M.D. $†$
}

DURING THE COURSE of an investigation into the haemodynamic changes which occur during haemorrhage we became interested in devising some method for the successful chronic implantation of catheters into various blood vessels, an essential procedure if an animal is to be studied on different occasions and the stress of implantation is to be avoided.

Barnstein et al. ${ }^{1}$ have recently investigated and reviewed the problem and reported their experience with various types of catheters used for chronic implantation. Their catheter of choice is made from extruded polyvinyl tubing (Surco S-1 clear). The main drawback to this method, we feel, is the need to fill the catheter with heparin to maintain patency.

This is a report of our experience with the problem.

\section{Materials}

Catheter-Obturator Complex (Fig. 1) $\$$

This consists of: (1) The catheter, made of Teflon; internal diameter .04 inches, tapering to .038 inches at the tip; outside diameter .061 inches. (2) A Metal Luer Lok hub, tapering to an eventual through-hole diameter of .042
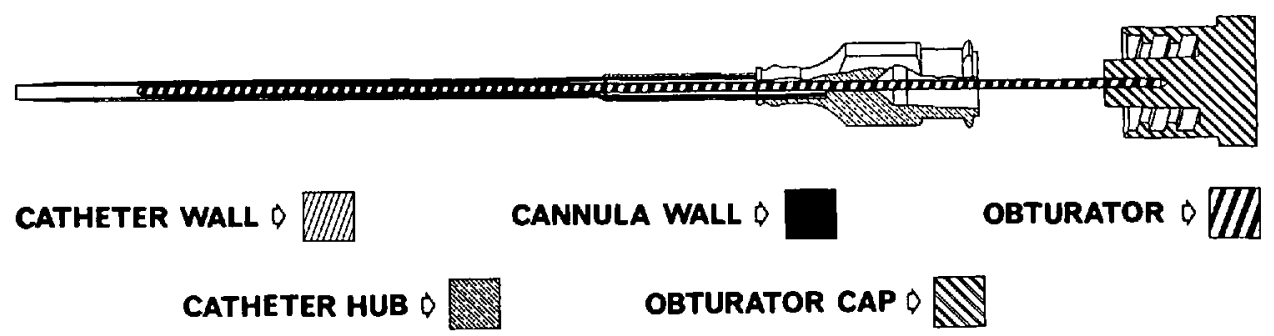

Figure 1. Sectional diagram of catheter-obturator complex.

inches and fitting into the proximal end of the catheter. (3) The obturator, also made of Teflon. Its point extends slightly beyond the end of the catheter tip when inserted. Its proximal end consists of a cap which connects firmly into the metal Luer Lok hub. The outside diameter of the obturator is .036 inches.

"This study has been supported by an operating grant from the Medical Research Council of Canada.

†Department of Anaesthesia, Toronto Western Hospital and University of Toronto.

\$Becton, Dickinson \& Co., Rutherford, N.J. 
Animals

Healthy mongrel dogs weighing 20 to $25 \mathrm{~kg}$. are used for each experiment.

\section{Other Equipment}

Statham pressure transducers and a Sanborn multi-channel recorder.

\section{METHOD}

Each dog is induced with a sleep dose of sodium thiopentone and the trachea is intubated. Maintenance of anaesthesia is continued with a mixture of oxygen 30 per cent, nitrous oxide 70 per cent. The animal is rendered immobile by use of a dilute solution of succinylcholine ( $500 \mathrm{mg} . / 500$ c.c. of 5 per cent dextrose in water) run as a continuous intravenous infusion. Respiration is controlled with a Jefferson ventilator.

The dog is placed in the left lateral position and the area over the left external jugular vein, left anterior fourth and fifth intercostal spaces is prepared and draped.

A small branch of the left pulmonary artery is exposed through a short left thoracotomy (fourth or fifth interspace). After it is mobilized, three silk sutures are passed beneath it. The vessel is then ligated distally by tying one of the sutures. The proximal end is opened and the catheter, with the obturator in situ, is passed into the left pulmonary artery (Fig. 2). Any haemorrhage ensuing during this period (especially if difficulty is encountered while attempting to

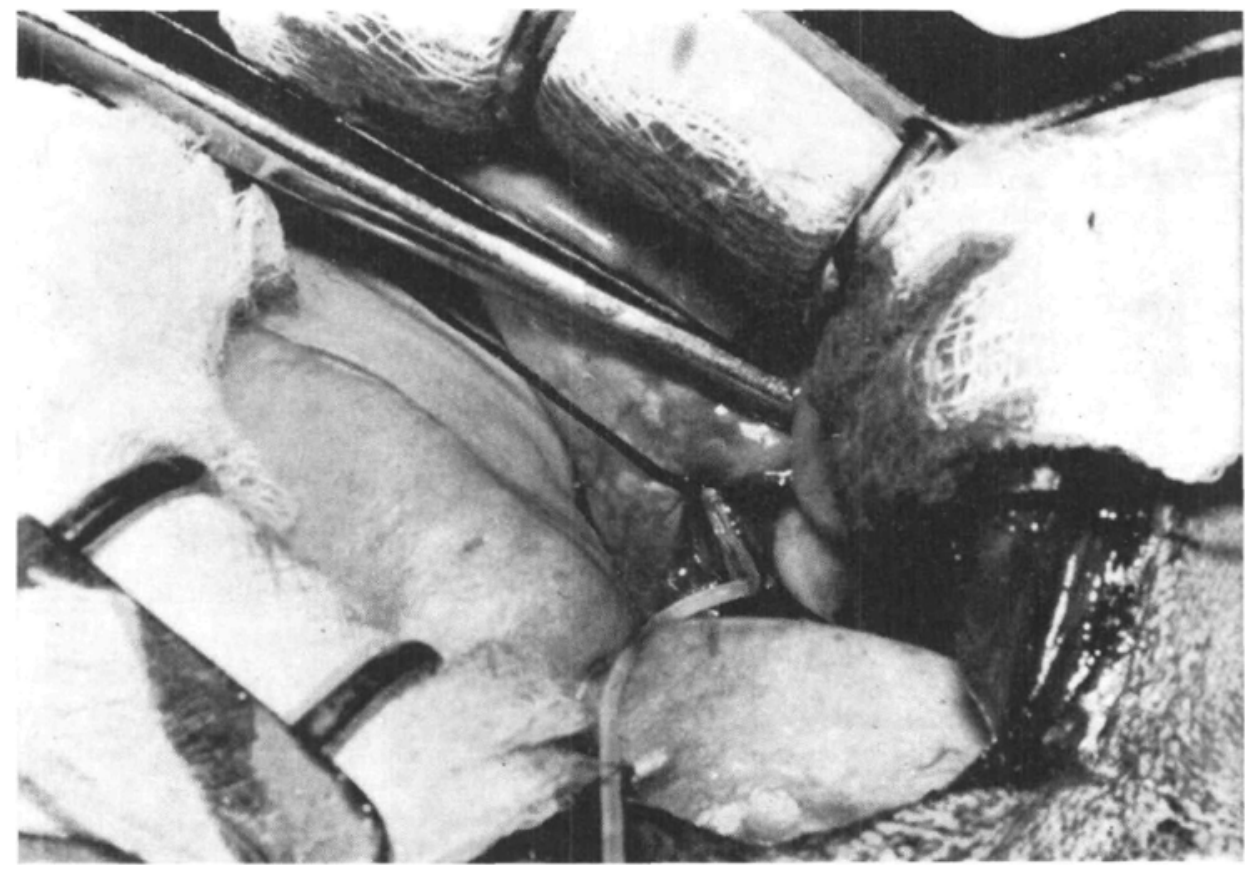

Figure 2. Branch of left pulmonary artery exposed with catheter in situ. 
enter the vessel) can be controlled by putting tension on the proximal sutures. The vessel is then anchored around the catheter with the two ligatures.

The obturator is withdrawn and the patency of the catheter is assessed by the ability to: (a) withdraw blood and flush the catheter easily, (b) obtain an undamped pressure tracing with a Statham pressure transducer and a Sanborn multichannel recorder. The obturator is then replaced. Occasionally moderate difficulty in passing the obturator is encountered at the site of ligation but only rarely has it been found necessary to replace one or both ligatures.

The chest is then closed in the usual fashion. The catheter makes a gentle curve outwards through the posterior end of the wound and is then brought anteriorly and placed 1 to 3 inches away from the incision. It is important to assess the patency of the catheter at various times during closure by the methods described previously.

In our experience, difficulty in withdrawing blood and damping of the tracing, combined with easy flushing and passage of the obturator, usually indicates that the catheter has come up against the wall of the left pulmonary artery (Fig. 3a). If flushing and passage of the obturator are difficult, then there is usually kinking of the small vessel through which the catheter enters the pulmonary artery (Fig. 3b). If any of these conditions apply, adjustments must be made in the position of the catheter. Any problems encountered at this stage tend to be exaggerated when the catheters are re-opened later.

Before placing the distal end of the catheter under the skin, pressure tracings are recorded for comparison with those to be taken at a future date.

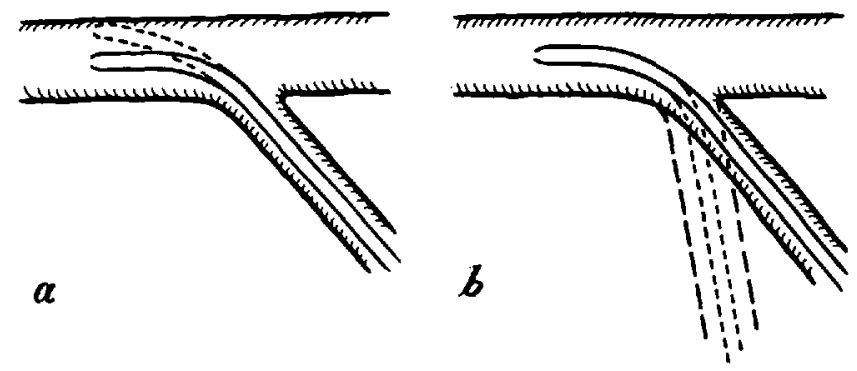

Figure 3. (a) Relationship of catheter and arterial wall which will lead to a check valve effect. (b) Acute angulation of catheter producing obstruction by kinking.

\section{External Jugular Vein}

The vein is exposed through a short vertical incision, and the catheter and obturator are placed and fixed into the superior vena cava in a fashion similar to that described for the pulmonary artery (Fig. 4). The distal end of the catheter is placed under the skin posteriorly.

\section{Femoral Artery}

After re-adjusting the position of the dog the left femoral artery is exposed and ligated distally. Again the catheters are placed in a fashion similar to that 


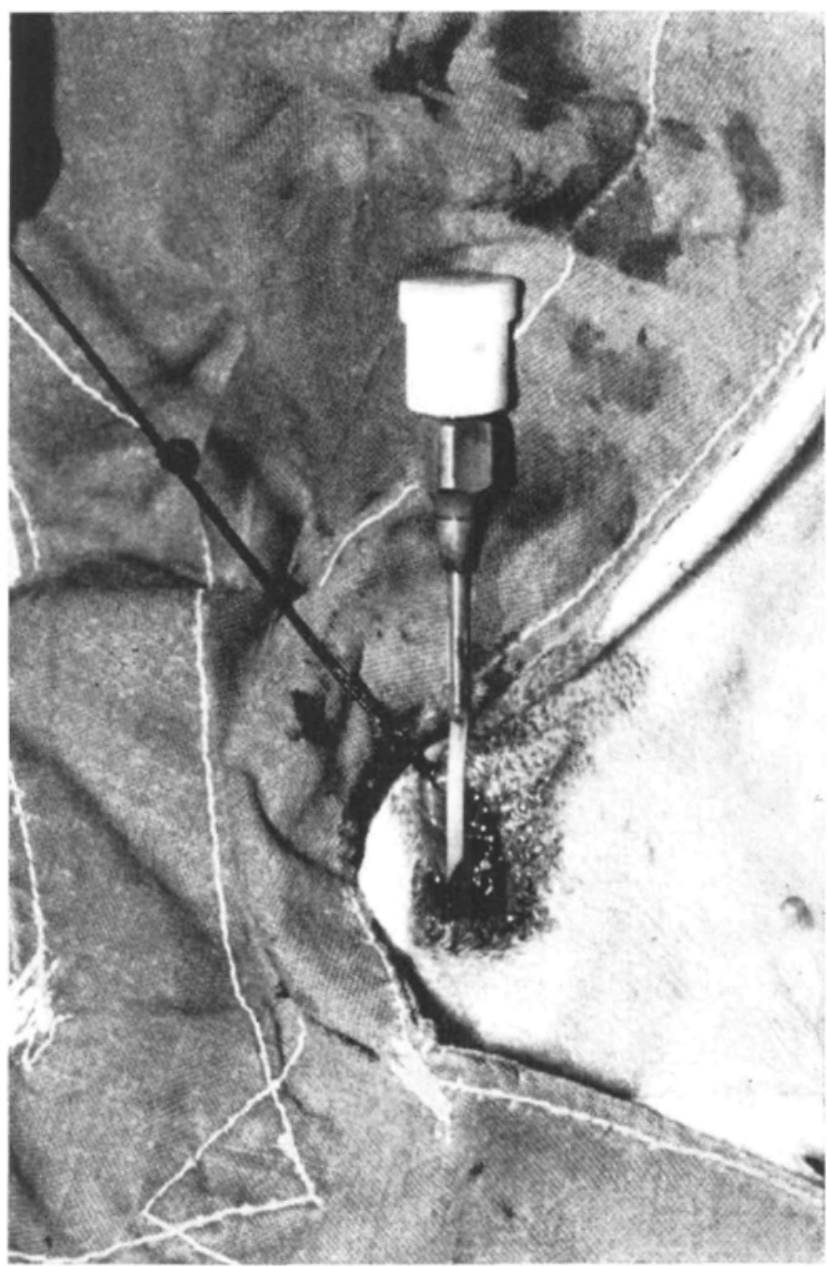

FIgure 4. Catheter in external jugular vein.

previously described. The dogs are then allowed to recover over a period of 10 to 30 days, and the distal ends of the catheter are exposed through small skin incisions (Figs. 5 and 6). The obturators are withdrawn and patency is confirmed. Pressure tracings are compared with those previously obtained. At the termination of the experiment the wounds are closed and the dog is allowed to recover. The experiment is repeated at a later date under different conditions.

\section{Results (TABLe I)}

Our early results as regards patency were somewhat unsatisfactory due to poor technique. As stated earlier, it is important to test the patency of the catheters at various stages of the closing procedure, especially when the pulmonary artery is the vessel cannulated.

Haemorrhage, of course, is always a potential problem. If the ligature around the pulmonary artery is too loose the catheter can easily slip out; on the other 


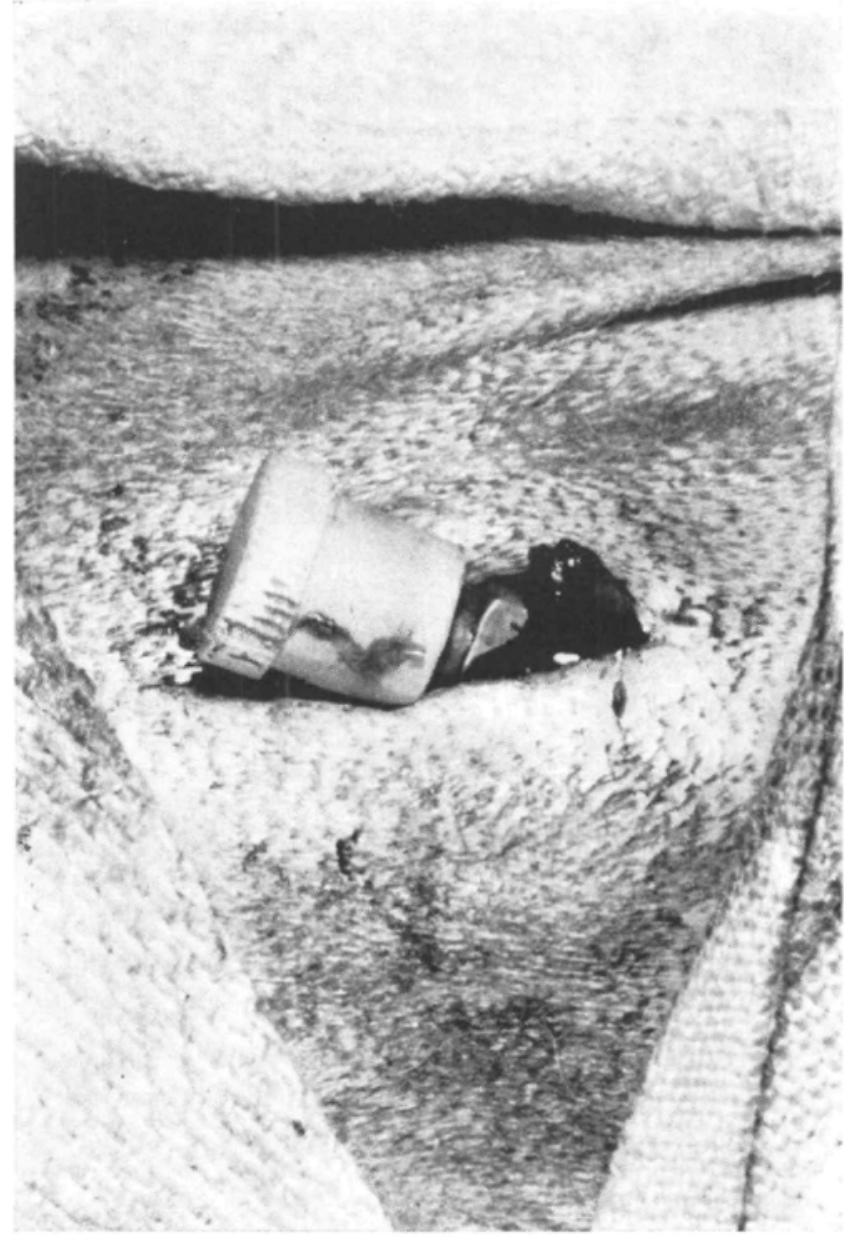

Figure 5

hand, if it is too tight, difficulty may be encountered in obtaining good, undamped tracings. A major problem with any chronic implantation technique using animals is trauma to the catheters and infection of the surgical areas. This has only been a minor hazard except when femoral artery catheterization has been done. It is important to place the hub of the neck catheters as far posteriorly as possible to stop the animal from biting the end off it. Dog 7 managed to do this.

Surprisingly, there have been few problems with ulceration of the catheter hub through the skin, even in the chest, where the skin may be initially quite tightly stretched. Although at first sight a smaller hub would appear to be an advantage, the larger one which we have used permits easy location after a number of weeks in situ.

With these exceptions, patency of the catheters has been very satisfactory. The longest implantation to date with good patency has been sixty days. However we have one pending which has been in situ over ninety days but which has not as yet had a final testing. 
TABLE I

\begin{tabular}{|c|c|c|c|c|c|c|c|}
\hline \multirow[b]{2}{*}{ Dog } & \multirow[b]{2}{*}{ Site } & \multirow{2}{*}{$\begin{array}{c}\text { Days } \\
\text { in situ }\end{array}$} & \multirow{2}{*}{$\begin{array}{l}\text { Number } \\
\text { of times } \\
\text { catheter } \\
\text { opened }\end{array}$} & \multicolumn{3}{|c|}{ Patency each time opened } & \multirow[b]{2}{*}{ Remarks } \\
\hline & & & & 1 & 2 & 3 & \\
\hline 1 & P.A. & 30 & 2 & ++ & - & & $\begin{array}{l}\text { Poor patency of catheter } \\
\text { attributable to operative } \\
\text { technique in retrospect; } \\
\text { only moderate patency } \\
\text { achieved at end of } \\
\text { initial operation. }\end{array}$ \\
\hline 2 & $\begin{array}{l}\text { P.A. } \\
\text { S.V.C. }\end{array}$ & $\begin{array}{l}34 \\
34\end{array}$ & $\begin{array}{l}2 \\
2\end{array}$ & $\begin{array}{l}+++ \\
++\end{array}$ & $\begin{array}{l}+++ \\
++\end{array}$ & & $\begin{array}{l}\text { Postoperative patency } \\
\text { good. }\end{array}$ \\
\hline 3 & $\begin{array}{l}\text { P.A. } \\
\text { S.V.C. }\end{array}$ & $\begin{array}{l}40 \\
40\end{array}$ & $\begin{array}{l}2 \\
2\end{array}$ & $\stackrel{+}{+}++$ & & & $\begin{array}{l}\text { Poor patency for same } \\
\text { reasons as in dog } 1 .\end{array}$ \\
\hline 4 & $\begin{array}{l}\text { P.A. } \\
\text { S.V.C. }\end{array}$ & $\begin{array}{l}53 \\
53\end{array}$ & $\begin{array}{l}3 \\
3\end{array}$ & $\begin{array}{l}+++ \\
+++\end{array}$ & $+t+$ & $\stackrel{+}{++}$ & \\
\hline 5 & $\begin{array}{l}\text { P.A. } \\
\text { S.V.C. }\end{array}$ & $\begin{array}{l}4 \\
4\end{array}$ & - & & & & $\begin{array}{l}\text { Death of animal due to } \\
\text { overwhelming chest } \\
\text { infection. }\end{array}$ \\
\hline 6 & $\begin{array}{l}\text { P.A. } \\
\text { S.V.C. }\end{array}$ & $\begin{array}{l}36 \\
36\end{array}$ & $\begin{array}{l}3 \\
3\end{array}$ & $\begin{array}{l}+++ \\
++\end{array}$ & $\begin{array}{l}+++ \\
++\end{array}$ & $\begin{array}{l}+++ \\
+++\end{array}$ & \\
\hline 7 & $\begin{array}{l}\text { P.A. } \\
\text { S.V.C. }\end{array}$ & $\begin{array}{l}52 \\
52\end{array}$ & $\begin{array}{l}3 \\
2\end{array}$ & $\begin{array}{l}+++ \\
++\end{array}$ & $\begin{array}{l}++t \\
++\end{array}$ & $+t+$ & $\begin{array}{l}\text { Dog opened neck wound } \\
\text { severed end of catheter }\end{array}$ \\
\hline 8 & $\begin{array}{l}\text { P.A. } \\
\text { S.V.C. }\end{array}$ & $\begin{array}{l}42 \\
42\end{array}$ & $\begin{array}{l}3 \\
3\end{array}$ & $\begin{array}{l}+++ \\
+++\end{array}$ & $\begin{array}{l}+++ \\
++t\end{array}$ & $\begin{array}{l}++ \\
++\end{array}$ & \\
\hline 9 & $\begin{array}{l}\text { P.A. } \\
\text { S.V.C. }\end{array}$ & $\begin{array}{l}42 \\
42\end{array}$ & $\begin{array}{l}2 \\
2\end{array}$ & $\begin{array}{l}+++ \\
++\end{array}$ & $\begin{array}{l}+++ \\
++\end{array}$ & $\begin{array}{l}+t+ \\
+t\end{array}$ & \\
\hline 10 & $\begin{array}{l}\text { P.A. } \\
\text { S.V.C. }\end{array}$ & - & - & & & & $\begin{array}{l}\text { Death on table from } \\
\text { massive haemorrhage. } \\
\text { Pulmonary artery } \\
\text { catheter had slipped out. }\end{array}$ \\
\hline 11 & $\begin{array}{l}\text { P.A. } \\
\text { S.V.C. }\end{array}$ & $\begin{array}{l}60 \\
60\end{array}$ & $\begin{array}{l}2 \\
2\end{array}$ & $\begin{array}{l}+++ \\
+++\end{array}$ & $\begin{array}{l}+t+ \\
++\end{array}$ & & \\
\hline 12 & $\begin{array}{l}\text { P.A. } \\
\text { S.V.C. }\end{array}$ & $\begin{array}{l}52 \\
52\end{array}$ & $\begin{array}{l}2 \\
2\end{array}$ & $\begin{array}{l}+++ \\
++\end{array}$ & $\begin{array}{l}++ \\
++\end{array}$ & & \\
\hline 13 & $\begin{array}{l}\text { P.A. } \\
\text { S.V.C. } \\
\text { F.A. }\end{array}$ & $\begin{array}{l}20 \\
20 \\
20\end{array}$ & $\begin{array}{l}1 \\
1 \\
1\end{array}$ & $\begin{array}{l}+++ \\
++t\end{array}$ & & & $\begin{array}{l}\text { Dog sacrificed due to } \\
\text { severe infection of groin } \\
\text { wound. }\end{array}$ \\
\hline 14 & $\begin{array}{l}\text { P.A. } \\
\text { S.V.C. } \\
\text { F.A. }\end{array}$ & $\begin{array}{l}10 \\
10 \\
10\end{array}$ & E & & & & $\begin{array}{l}\text { Sudden death. No obvious } \\
\text { reason. Groin wound } \\
\text { infected. }\end{array}$ \\
\hline 15 & $\begin{array}{l}\text { P.A. } \\
\text { S.V.C. } \\
\text { F.A. }\end{array}$ & $\begin{array}{l}30 \\
30 \\
30\end{array}$ & $\begin{array}{l}2 \\
2 \\
2\end{array}$ & $\begin{array}{l}+++ \\
+++ \\
+++\end{array}$ & $\begin{array}{l}+++ \\
+++\end{array}$ & & $\begin{array}{l}\text { Femoral artery catheter } \\
\text { non-functioning on } \\
\text { second opening. }\end{array}$ \\
\hline 16 & $\begin{array}{l}\text { P.A. } \\
\text { S.V.C. }\end{array}$ & $\begin{array}{l}40 \\
40\end{array}$ & $\begin{array}{l}3 \\
3\end{array}$ & $\begin{array}{l}+++ \\
++\end{array}$ & $\begin{array}{l}+++ \\
++\end{array}$ & $\begin{array}{l}+++ \\
++\end{array}$ & \\
\hline 17 & $\begin{array}{l}\text { P.A. } \\
\text { S.V.C. }\end{array}$ & $\begin{array}{l}52 \\
52\end{array}$ & $\begin{array}{l}3 \\
3\end{array}$ & $\begin{array}{l}+++ \\
+++\end{array}$ & $\begin{array}{l}+++ \\
+++\end{array}$ & $\begin{array}{l}+++ \\
++\end{array}$ & \\
\hline 18 & $\begin{array}{l}\text { P.A. } \\
\text { S.V.C. }\end{array}$ & $\begin{array}{l}28 \\
28\end{array}$ & $\begin{array}{l}2 \\
2\end{array}$ & $\begin{array}{l}+++ \\
++\end{array}$ & $\begin{array}{l}++t \\
++t\end{array}$ & & \\
\hline 19 & $\begin{array}{l}\text { P.A. } \\
\text { S.V.C. }\end{array}$ & $\begin{array}{l}44 \\
44\end{array}$ & $\begin{array}{l}2 \\
2\end{array}$ & $\begin{array}{l}+++ \\
+++\end{array}$ & $\begin{array}{l}+++ \\
+++\end{array}$ & & \\
\hline 20 & $\begin{array}{l}\text { P.A. } \\
\text { S.V.C. }\end{array}$ & $\begin{array}{l}46 \\
46 \\
\end{array}$ & $\begin{array}{l}2 \\
2 \\
\end{array}$ & $\begin{array}{l}+++ \\
+++\end{array}$ & $\begin{array}{l}++t \\
+t+\end{array}$ & & \\
\hline
\end{tabular}

LEGEND:

P.A. Pulmonary artery

S.V.C. Superior vena cava

F.A. Femoral artery

$+\quad$ Poor patency: pressure tracing unobtainable or severely damped.

+ Fair patency: pressure tracing moderately damped.

+++ Good patency: undamped pressure tracing. 


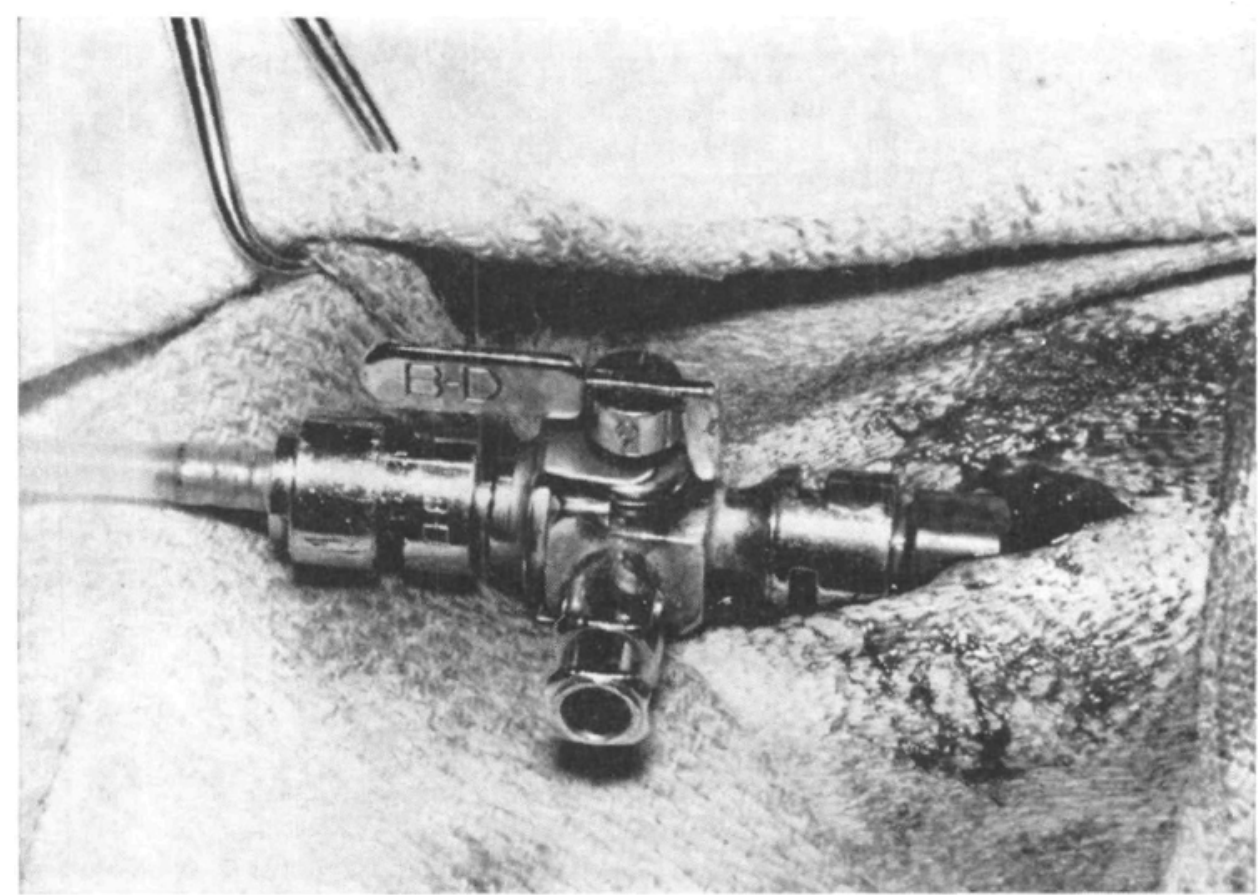

Frgure 6

The small incisions needed to expose the proximal ends of the catheters have not increased the morbidity, and healing has been satisfactory. We have had no problems to date with intravascular clotting in the superior vena cava. As Barnstein et al. ${ }^{1}$ and Derrick ${ }^{2}$ have pointed out, there does seem to be a direct relationship between the length of catheter lying in the vessel and the incidence of thrombosis, but only in the femoral artery has there been any gross evidence of intravascular clatting (dogs 14 and 15). However, no micro- or macroscopic pathological studies of the catheterized blood vessels have been done; these studies are to be carried out at a future date.

\section{SUMMaRY}

This has been a report on the chronic implantation of catheters into various blood vessels. A description of the catheter used has been given, the operative technique is described, and results are tabulated.

\section{ACKNOWLEDGMENT}

We wish to thank Becton, Dickinson \& Co. for the preparation of Figure 1 .

\section{REFERENCES}

1. Barnstein, N. J.; Gilfillan, R. S.; Pace, N.; \& Rahlmann, D. F. Chronic Intravascular Catheterization: A Technique for Implanting and Maintaining Arterial and Venous Catheters in Laboratory Primates. J. Surg. Res. 6: 511 (1966).

2. Derrick, J, R. Effect of Prolonged Use of Indwelling Aortic Catheters. Surgery, 54: 343 (1963). 